\title{
The Monetary Control Act, Reserve Taxes and the Stock Prices of Commercial Banks
}

\section{G. J. Santoni}

INCE 1980 all depository institutions have been required to hold reserve balances in the form of Treasury coins and Federal Reserve notes either in their own vaults or on deposit at their regional Federal Reserve Banks. These reserve balances pay no interest, so the foregone interest earnings on the investments the firm could otherwise have made can be viewed as a $\operatorname{tax}^{1}$

This tax lowers the firm's expected stream of future income net of taxes which, other things the same, reduces the capital value of the firm. The tax varies with the general level of interest rates as well as the spread between bank lending and borrowing rates. Prior to 1980, the tax had differential effects across banks depending on the tax rate (required reserve ratiol faced by these various firms. This was particularly true with respect to member vs. nonmember banks of the Federal Reserve System.' These differential tax effects are important. Equity considerations aside, they artificially raise the operating costs of some firms relative to others engaged in essentially the same business activity. This distorts rates of production and the allocation of resources among the differentially taxed firms and lowers the value of output for given costs.

The Monetary Control Act of 1980 imposed uniform reserve requirements on all depository institutions by raising reserve requirements for nonmember banks, while lowering them for member banks. The purpose

G.J. Santoni is a senior economist at the Federal Reserve Bank of $5 t$. Louis. Thomas A. Pollmann provided research assistance. This paper was produced in conjunction with the Center for Banking Research at Washington University in St. Louis and appears in the working paper series published by that institution.

For discussions of the effects of differential reserve requirements, see Fama (1985); Cargill and Garcia (1982); Gibert (1978); Gilbert and Lovati (1978); Prestopino (1976); Goldberg and Rose (1976) and Knight (1974).

2See Goldberg and Rose (1976) and Prestopino (1976). of this article is to analyze the effect this legislation has had in eliminating the differential tax effect of interest rate changes on member vs. nonmember banks. In particular, the paper examines whether the act was effective in revising the response of bank capital values (stock prices) to interest rate changes. Since any revision in differences in tax rates between groups generally benefits one group over another, the paper provides some rough estimates of this as well.

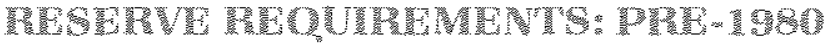

Prior to the Monetary Control Act, reserve requirements for nonmember banks were set by the various state banking authorities. These differed across states with respect to the reserve ratio, the form in which the reserves were required to be held, the method and frequency of policing and the penalty imposed for deficiency: While differences existed, the reserve requirements of state banking authorities generally were more lenient than those of the Federal Reserve System. This appears to have been so with respect to the form of the reserves, policing and penalties for deficiency.

Specifically, 30 of the 50 state banking authonities allowed banks to hold at least a portion of their reserves in interest-earning assets, 36 states did not require periodic repotting of reserve and deposit bal* ances and 22 had no monetary penalty for deficient banks. In contrast, Fed members had to hold reserves either in their vaults of on deposit at a Federal Reserve Bank. These reserve balances earned no interest. Member banks reported their deposit and reserve balances to the Fed on a weekly basis, and a monetary penalty was enforced for deficient banks.

The left side of table 1 gives the reserve require-

3See Gilbert and Lovati (1978), Prestopino (1976) and Knight (1974),

${ }^{4}$ See Gibert and Lovati (1978), p. 32, and Knight (1974), p. 12-13, for listings of the various state requirements.

sSeven states imposed reserve requirements that were roughly identical to those of Fed members. These states were Arkansas, California, Kansas, Nevada, New Jersey, Oklahoma and Utah. Nonmember banks in these states are excluded from the data sample in the tests conducted below. 
Table 1: Depository Institutions' Reserve Requirements (percent of deposits)'

\section{Type of deposit and}

Nel demand?

$\$ 0-2$

$2-10$

$10-100$

$100-400$

over 400

\section{Tine and savings $=1$}

Savings

Times

$0-5$ by maturity
30 - 179 days
180 days to 4 years
4 years or more
over 5 , by maturity
$30-179$ days
180 days to 4 years
4 years or more

Nember bank requirements betore implementation of the Monetary Control Act

Percent Effective date

Percent Effective date

\begin{tabular}{|c|c|}
\hline $7 \%$ & $12 / 30176$ \\
\hline $9 / 2$ & $12 / 30 / 7$ \\
\hline $113 / 4$ & $1230 /$ \\
\hline 123,4 & 1230 \\
\hline $16 \%$ & 12 \\
\hline
\end{tabular}

$3 \%$

316667

$$
\begin{aligned}
& 3 \\
& 2 \% \\
& 1 / 2 \\
& 2_{2} / 2 \\
& 1
\end{aligned}
$$$$
3 / 16,67
$$

मे

-

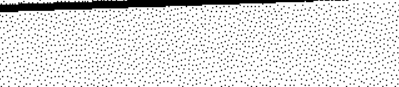

Type ol deposit and deposit interval (millions of dollars)

Net transaction accounts?

$\$ 0 \$ 29.8$

Over $\$ 298$

Nonpersonal time deposits

By orgenal maturity

Less than 4 yedrs

4 years or nore

\section{Eurocurrency llabilities}

Altypes
Depository

institution requirements

after implementation of the

Monetan Control Acts

Percent Eftective date

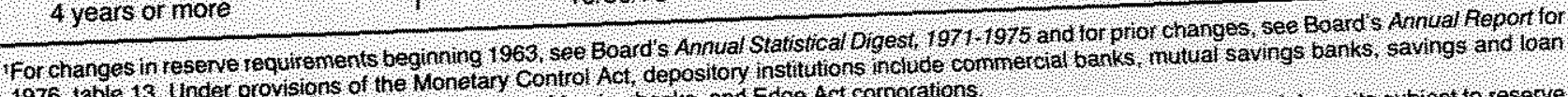

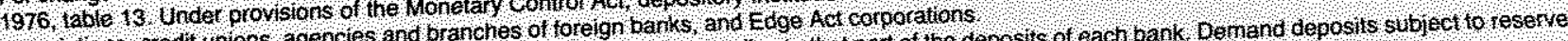

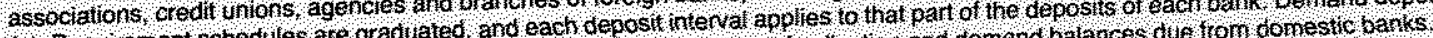

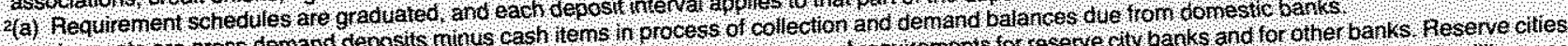

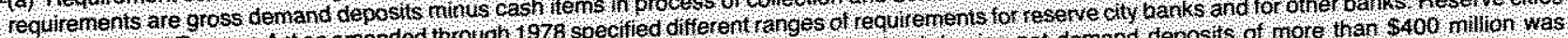

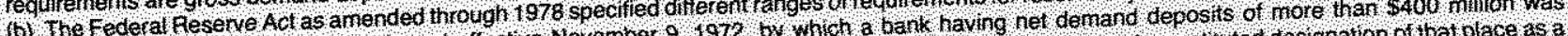
(b) Dof

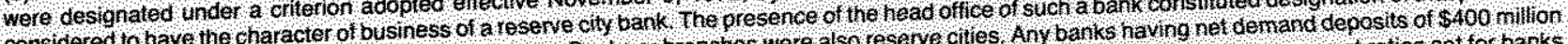

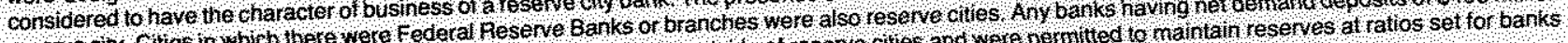

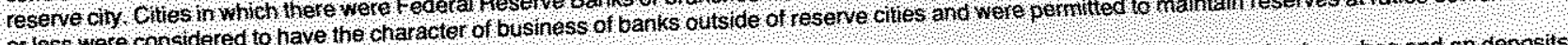
or less wore oonster

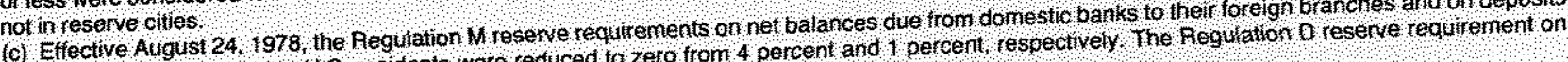

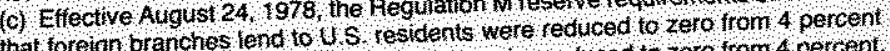

That foleigh brances to the same reserve

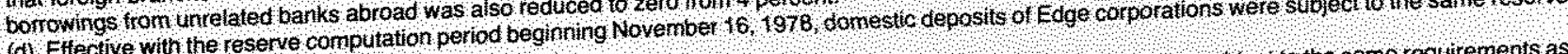
(d) Effective with the esere computation pend

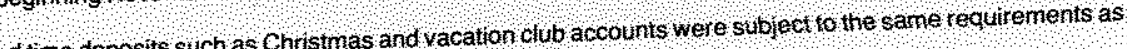

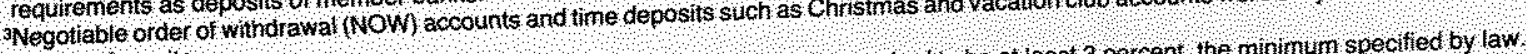

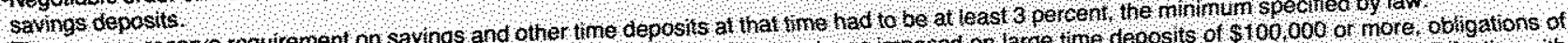

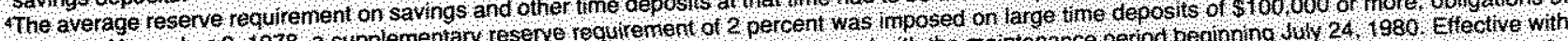

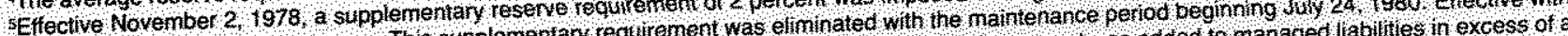
E aftliates and neligiole acceptances.

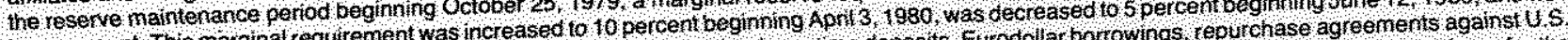

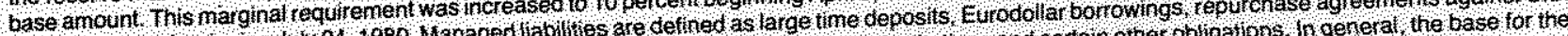

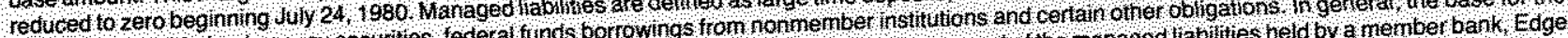

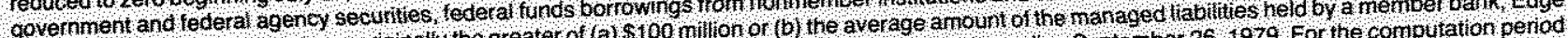

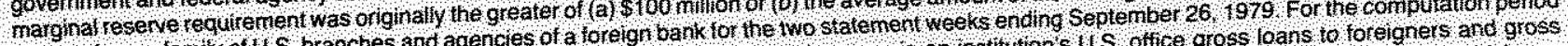

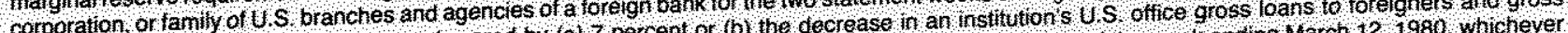

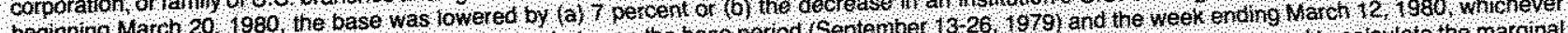

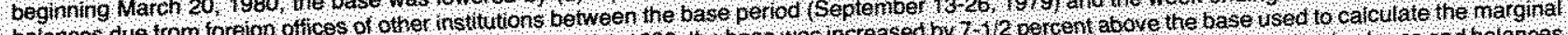

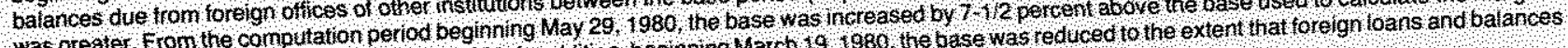

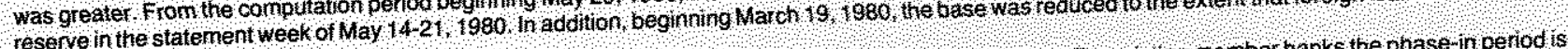
resorvelf

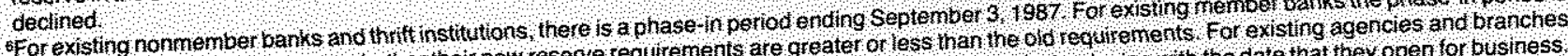

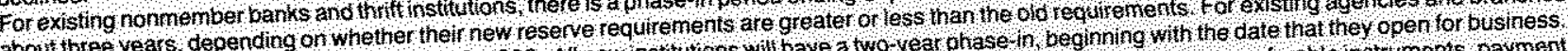

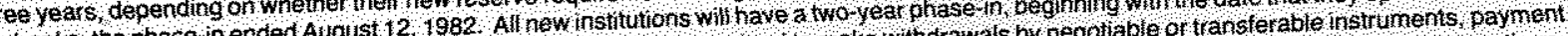

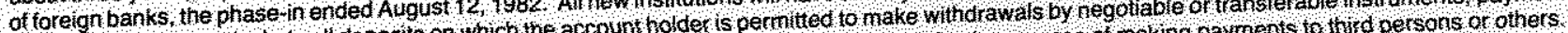

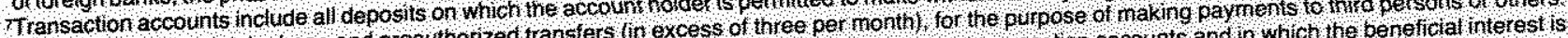

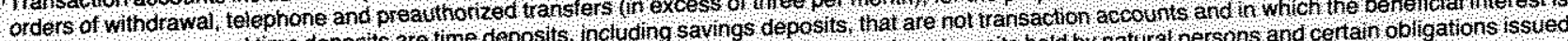

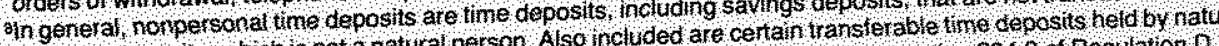

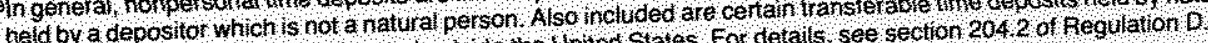

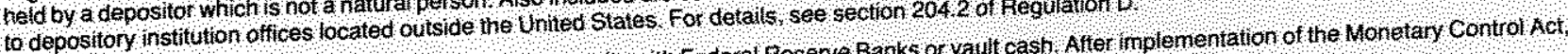

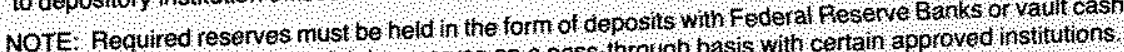
nonmembers may maintan reserves on a pass through basis with certain approved 


\section{Table 2}

\section{Member Bank Foregone Interest on Reserve Balances (millions of dollars)}

\begin{tabular}{|c|c|c|}
\hline Net Demand & Required Reserves & $\begin{array}{l}\text { Foregone Interest When } \\
\qquad \mathrm{i}=.08^{\mathrm{s}}\end{array}$ \\
\hline$\$$ & $\$ 0,00$ & $\$ 0.000$ \\
\hline 2 & 0.14 & 0.011 \\
\hline 10 & 0.90 & 0.072 \\
\hline 25 & 2.66 & 0.213 \\
\hline 100 & 1148 & 0.918 \\
\hline 400 & 5000 & 4.000 \\
\hline 1,000 & 14750 & 11.800 \\
\hline 2,000 & 31000 & 24,800 \\
\hline 5,000 & 797.50 & 63.800 \\
\hline
\end{tabular}

Foregone interest $=x$ required reserves

ments that applied to Federal Reserve member banks before November 1980." These reserve ratios were at least as high as those imposed by the various state banking authorities for nonmember banks and. in most cases, they were higher. ${ }^{*}$

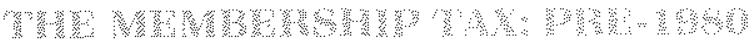

Other things the same, the more stringent reserve requirements for Fed members raised the cost of maintaining a given level of deposits relative to the cost experienced by nonmembers. Table 2 uses the data in table 1 to calculate the tax for member banks at various levels of net demand deposits. ${ }^{H}$ For example, a member bank with $\$ 100$ million in net demand deposits was required to hold $\$ \mathbf{\$ 1 . 4 8}$ million in reserves. This resulted in foregone eamings of $\$ 918,000$ per year if the market rate were 8 percent." The decline in the expected stream of earnings was the reserve fax in this case, $\$ 918,000$ per yearl. Since the capital value of a firm is the present value of its expected earnings stream, the tax reduced the capital value of the bank as well.

${ }^{6}$ The Monetary Controt Act was passed in March 1980, but the new reserve requirements did not become effective immediately. The right side of the tabie indicates the reserve rectirements that would have been imposed as of November 13,1980, if there had been no phase in period. In fact, these new requirements were phased in over a period of years (see table 1, note 6). For the moment, the discussion is focused on pre-November 1980 reserve requirements.

7 See Gilberi and Lovati (1978) for a listing of the reserve ratios imposed by the various state authorities.

sThe calculation is intended for illustrative purposes only and ignores the foregone interest on reserves held against time deposits.

This represents an upper bound to the tax since the bank would maintain some reserves even if there were no legal requirement to do so.

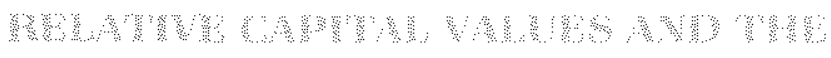

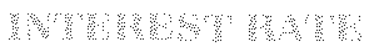

Not only does the reserve tax reduce the expected earnings streams and capital values of member banks (those with higher reserve requirements) relative to nonmember banks, but the earnings streams and capital values of member banks change relative to nonmember banks with changes in either the general level of interest rates or the spread between bank borrowing and lending rates.

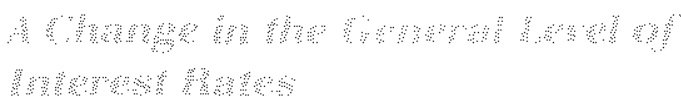

Table 3 illustrates the effect of a change in the level of interest rates with the spread held constant. In panel $A$, the rate at which banks can lend is assumed to be 10 percent, while the rate paid on deposits land other sources of funds) is 5 percent. The reserve requirement for member banks is assumed to be 10 percent. For illustrative purposes, the non-interestearnings reserves of nonmembers are assumed to be zero. The table calculates the amount available for lending, the annual net revenue and the capital value of the net revenue stream for each $\$ 100$ of deposits for both a member and a nonmember bank.

The reserve requirement lowers the amount that can be loaned, the stream of net revenue and capital value of the member relative to the nonmember bank. The capital value of the member's revenue stream is $\$ 40$, while the nonmember's is $\$ 50$. The member's capital value relative to the nonmember's is 80 percent. Notice that the absolute difference between the two capital values is equal to the required reserves of members $(\$ 50-\$ 40=\$ 10)$.

In panel $\mathrm{B}$, both lending and borrowing rates are assumed to increase to 20 percent and 15 percent, respectively, while other things remain the same. ${ }^{\text {th }}$ The net revenue stream of the nonmember does not change while the member's stream falls. The increase in interest rates causes the capital value of both banks to decline. More importantly, however, the capital value of the member bank drops from 80 percent to 60 percent in terms of the capital value of the nonmember bank.

Notice that, in this particular case, the absolute

II In the example, the absolute spread is unchanged but the relative spread $\left(i_{G} / h_{1}\right)$ changes. If the ratio of the borrowing to the lending rate remained constant as the general level of interest rates changed, relative capital values would not change. The example is intended for illustrative purposes. A more precise statement of the effect of interest rate changes is given in the appendix. 
Table 3

\section{A Change in the General Level of Interest Rates and Relative Capital Values'}

\begin{tabular}{l} 
P \\
\hline
\end{tabular}

Conditions of the example are that deposits of both banks are $\$ 100$, the required reserve ratio for members is 10 percent and zero for nonmembers.

difference between the capital values of the two banks does not change. This is because the banks in this example have the same level of deposits and, thus, the differential effect caused by member bank reserve requirements remains constant isee the appendix for a more formal presentationt.

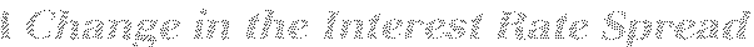

Table 4 is similar to table 3 except that it illustrates the effect on relative earnings streams and capital values of a change in the spread between the interest rate banks charge on loans and the rate paid on deposits. The top halves of the two tables are identical. In panel $B$ of table 4, however, the lending rate is assumed to increase while the borrowing rate remains unchanged. The earning streams and capital values of both banks rise with the capital value of the member rising relative to that of the nonmember.

In this example, the interest rate spread increases as the bank lending rate rises, while the borrowing rate remains the same. A qualitatively similar result would occur if the borrowing rate declined, while the lending rate remained the same.

While changes in the spread are potentially important, two problems arise when testing for this effect. First, prior to 1981, the interest rate banks could pay on deposits was subject to a ceiling. During much of the earlier portion of the sample period used here, the ceiling was effective. As a result, changes in the spread were highly correlated with changes in the general level of interest rates. Second, the spread between lending and borrowing rates is the compensation 
Table 4

\section{Changes in the Interest Rate Spread and Relative Capital Values'}

\begin{tabular}{|c|c|c|c|}
\hline & Hembers & Nonmembers & $\begin{array}{l}\text { Relative } \\
\text { Capital Value }\end{array}$ \\
\hline \multicolumn{4}{|l|}{ Panel A Lending rate $=10 \%$} \\
\hline Deposit & $\$ 100$ & $\$ 100$ & \\
\hline Available for lending & $\$ 90$ & $\$ 100$ & \\
\hline $\begin{array}{l}\text { Annual revenue }(10 \times \text { Loan) } \\
\text { Cost }(05 \times \text { Deposit })\end{array}$ & $\$ 9$ & $\$ 10$ & \\
\hline Nelrevenue & $\$ 4$ & $\$ 5$ & \\
\hline Capital value (Netrevenue/ 10$)$ & 840 & $\$ 50$ & 80 \\
\hline \multicolumn{4}{|l|}{ Panel B. Lending rate $=20 \%$} \\
\hline Deposit & 5100 & $\$ 100$ & \\
\hline nequired resenes & 10 & ڤै & \\
\hline Avallable for lending & $\$ 90$ & 8100 & \\
\hline Annual revenue ( 20 \% $\times$ Loan) & $\$ 18$ & $\$ 20$ & \\
\hline Net revenue & $\$ 13$ & $\$$ & \\
\hline Capital value (Net revenue/20) & $\$ 65$ & $\$ 75$ & 87 \\
\hline
\end{tabular}

The conditions of the example are that deposits for both banks are $\$ 100$, the required reserve ratio for nember banks is 10 percent, both banks pay 5 percent on deposits, and both extend loans at the same interest rate, in panel $A$ the loan rate is 10 percent while, in panel $B$, the loan rate is 20 percent. The borrowing rate does not change. The firms cost of capital is assumed to equal the lending rate.

banks earn for employing their specialized resources to intermediate financial transactions. When borrowing and lending fates are free to move, as was true after 1981, competition among intermediaries assures that the spread is just sufficient to cover costs. Unless there is a change in the technology of the intermediation process, there is little reason to expect the spread to vary significantly. For these reasons, the spread is excluded in the following empirical analysis and attention is focused on variation in the level of interest rates. ${ }^{n}$

\footnotetext{
"In regressions not reported here, the product of a dummy variable and various proxies for the spread were tested. The dummy variable was used to control for the period of deposit rate ceilings that prevailed prior to 1981 . The dummy variable assumed a value of one for the period since relaxation of the interest rate ceilings on deposits (/1981-IV/1983), and zero otherwise. The coefficient of
}

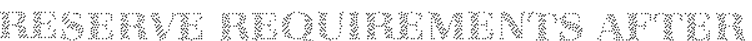

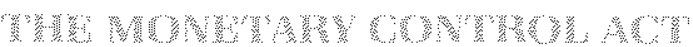

The right side of table 1 shows the reserve requirements of depository institutions after the implementation of the Monetary Control Act.: ${ }^{2:}$ These reserve requirements apply to depository institutions regardless of Fed membership. They substantially reduce the required reserve balances of member banks

\footnotetext{
this variable did not differ significantly from zero. The proxies for the lending rate used to calculate the spread were the one-month commercial paper rate, the $4-6$ month commercial paper rate and the 90-day bankers acceptance rate. The borrowing rate proxy was the Federal Reserve discount rate.

12See table 1 , note 6 , for a discussion of the period over which the new requirements were phased in. In the text, the phase-in period is ignored unless otherwise mentioned.
} 
at each level of net demand deposits, while generally increasing them for nonmember banks.

Table 1 also presents the pre- and post-reserve requirements on time and savings deposits. Before the Monetary Control Act, required reserve holdings against personal and nonpersonal time deposits ranged from 1 to 6 percent (with a minimum average requirement of 3 percent), while those on savings deposits were 3 percent. The act reduced these requirements to zero for personal time and savings accounts." Since these deposits represent a substantial portion of total time and savings deposits, this change results in a significant reduction in member bank required reserves. ${ }^{\mathrm{s}}$ Furthermore, the reserve requirement on managed liabilities and the supplementary reserve requirement on time deposits of $\$ 100,000$ or more were reduced to zero in July 1980.

While the change in the level of required reserves mandated by the act is clearly important for some issues, what is most important for the purpose of this paper is that this legislation imposes uniform reserve requirements across member and nonmember banks. (See the insert on page 18 for a discussion of some other provisions of the act.)

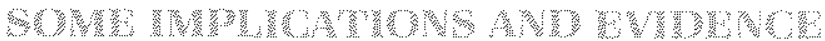

The phase-in period for the new reserve requirements, which extended through 1984 for member banks, will not be complete for nonmembers until September 1987. This will mitigate the quantitative effect of the change on the following estimates but the expected qualitative effect should show through.".

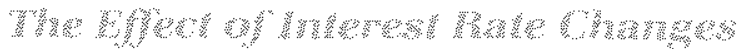 ary}

In an effort to evaluate the implications of the above argument, quarterly data on the share prices and demand deposit liabilities of $\mathbf{4 0}$ publicly traded bank holding companies were examined. The holding companies were divided into two categories depending on

\footnotetext{
${ }^{2}$ See table 1, note 8 , for a definition of personal vs. nonpersonal time and savings deposits.

${ }^{14}$ For example, for banks in the Eighth Federal Reserve District, the personal portion of savings deposits was more than five times greater than the nonpersonal portion, while the personal portion of time deposits was more than four times the nonpersonal portion.

${ }^{15}$ See Pearce and Roley (1983) and (1985).
}

whether the subsidiary banks making up an individual holding company were members or nonmembers of the Federal Reserve System." The stock prices of each holding company were adjusted for stock splits and stock dividends, and simple quarterly averages of stock prices and demand deposit liabilities were computed for each of the two categories of holding companies. The sample period runs from $1 / 1974-\mathrm{IV} / 1983$.

The previous arguments imply that the capital values of member relative to nonmember banks will be related in a specific way to certain other variables. Consequently, the variable to be explained (dependent variablel in the following regression is the ratio of the average stock prices of member to nonmember banks. For purposes of the empirical estimate, the dependent variable is expressed in log form.

The following empirical analysis is primarily concemed with the relationship between the dependent variable and the level of interest rates. Since an increase in the level of interest rates is thought to reduce member bank capital values relative to those of nonmember banks, the sign of the estimated coefficient on the level of interest rates is expected to be negative. Further, the above arguments indicate that the relationship between these variables will change in a particular way following implementation of the Monetary Control Act. ${ }^{1-}$ Consequently, an interaction term is included in the regression as an independent variable. $^{18}$

The interaction term is included to test for the effect that the Monetary Control Act has had in eliminating the differential response of the capital values of members vs. nonmembers to interest rate changes. The interaction term is the product of a coefficient to be estimated), a dummy variable and the level of the interest rate. The dummy variable assumes a value of one for the period subsequent to implementation of the Monetary Control Act, while its value is zero during the earlier period. Since the hypothesis suggests that the uniform reserve requirements embodied in the legislation will eliminate the adverse conse-

\footnotetext{
15 The data set includes only state-chartered banks. Nationally chartered banks are required to be members of the Fed, but are excluded from this sample mainly because they are much larger on average than state-chartered banks and are subject to different regulatory agencies.

${ }^{17}$ See the appendix for a summary of the theory that underies the estimating equation.

${ }^{18}$ The proxy employed for the general tevel of interest rates is the corporate Aaa bond rate. A longterm interest rate was selected since it is presumed to represent some average of current and expected future shorter-term interest rates.
} 


\section{Chart 1}

\section{Ratio of Member Banks to Nonmember Banks}

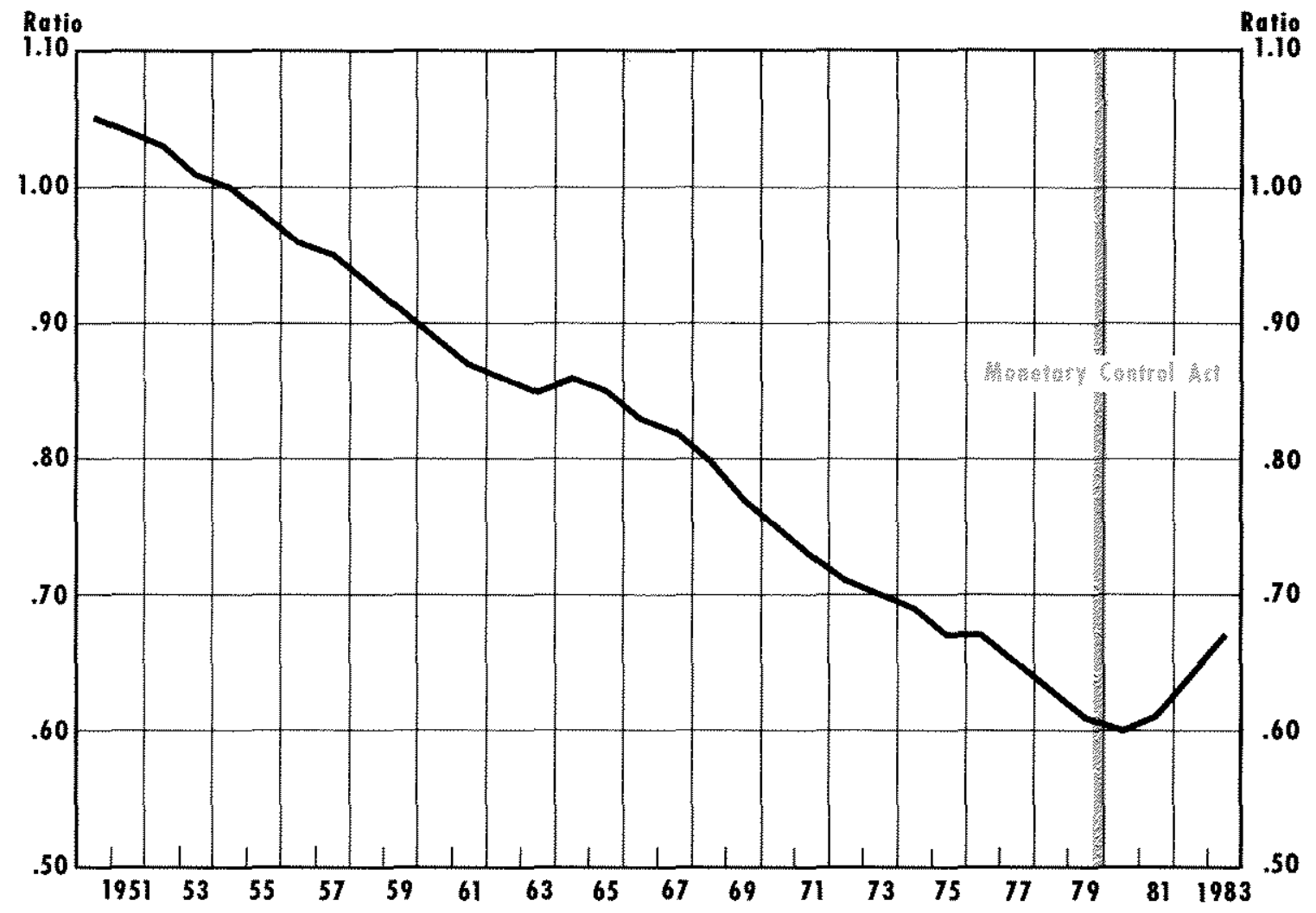

\section{Some Other Provisions of the Act}

The Monetary Control Act contains many other provisions that have important implications for financial firms and markets that are distinct from its impact on required reserves. Most of these provisions are not expected to affect member banks any differently than nonmember banks. There are two exceptions, however

Before the Monetary Control Act, the Federal Reserve System provided certain services to members that were free of direet charge. In addition, nembers were allowed to borrow from the system at the Federal Reserve discount rate. Neither of these services were avaliable to nonmember banks. The Federal Reserve System is now required by the Monetary Control Aet to charge for the banking services it provides and to make these services avaitable to any bank that wants to use them. In addition, borrowing from the Fed is no longer the exclusive privilege of member banks:

The effect of these two changes is to raise the capital values of nonmenber banks relative to member banks and to offset the effect of the reserve requirement changes, It is unlikely, however, that these two provisions of the act completely offset the effect of the reserve requirement changes on rela tive capital values Prior to 1980, Federal Reserve membership was declining both absolutely and relative to all commercial banks (see chart 1). The most frequently mentioned reason for leaving was the System's higher reserve requirements. Clearly, for the banks that decided to leave and those new banks that did not join, the System's reserve re quirements were too high a price to pay for "free" services and access to the discount window.

See Brewer (1980) 
Table 5

The Monetary Control Act and the Stock Prices of Member Vs. Nonmember Banks

Estimate

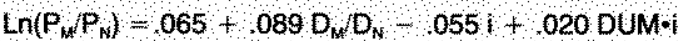
(36)
$(2.89)^{*}$
$(4.68)^{\prime}(4.56)$

$\mathrm{R}=54$

Fho $=-30$

$(2,02)^{*}$

where $P P_{N}=$ the average stock ptice of member banks relative to the average for nonmember banks

$\mathrm{D}_{N} \mathrm{O}_{N}$ = the average level of member bank demand deposit liabilites relative to the average for nonmember banks

1 a a proxy for the general level of niterest rates. The proxy is the level of the corporate Aaa bond rate

DUM $=$ a dummy varable for the period since implementation of the Monetary Control Act. $\mathrm{DUM}=1$ for the period $1 / 1981$ /V/1983 and zero otherwise?

Significantly different from zero at the 5 percent level

t-values in parentheses, Adjusted for first-order autocorrelation. The regression was checked for second-order autocorrelation with the following result Rho $2=07, \mathrm{t}$ value $=46$.

The estimate deteriorates if $\mathrm{D}=1$ for the period $1 / 1980 \mathrm{~N} / 1983$ and zero otherwise. This definition includes the period between March 1980 when the legislation was passed and November 1980 when it was implemented.

quences experienced by member banks when the general level of interest rates rise, the expected sign of the coefficient on the interaction term is positive. Were it not for the phase-in period, the absolute values of this coefficient and the coefficient on the level of interest rates would be the same, indicating that the elimination of differential reserve requirements completely eliminates the differential response of member bank capital values to the level of the interest rate.

Finally, the ratio of member to nonmember demand deposit liabilities is included as a scale variable. The sign of the coefficient on this variable is ambiguous. However, variation in the size of members relative to nonmembers can affect the dependent variable (see appendix) and, if the regression does not control for this variation, it can contaminate estimates of the other coefficients.

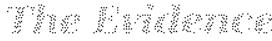

Table 5 presents the results of the regression. The variable included to control for differences in the scale of the two types of banks is significant and positive.

For the purposes of this paper, the coefficients on the interest rate and the interaction term are the most interesting. As expected, the coefficient on the interest rate is negative and significant, indicating that a higher interest rate is associated with a lower value of the dependent variable.

The sensitivity of the dependent variable to interest rate changes is measured by its interest rate elasticity. An estimate of the average elasticity during the period prior to the Monetary Control Act is given by the product of the coefficient of the interest rate and its average level ( 8.7 percent). In this case, the interest rate elasticity is estimated to be $-.48 i=.055 \times 8.7$ !. This indicates that a 1 percent increase in the interest rate reduces the share prices of member relative to nonmember banks by about 0.5 percent.

Implementation of the Monetary Control Act appears to have mitigated this differential effect. The sign of the interaction term is positive and significant. The coefficient, however, is less in absolute value than the coefficient of the interest rate. This is not surprising given that the new reserve requirements were phased in and that the phase-in will continue through 1987.

As of this point in the phase-in (TV/1983), and with the average level of interest rates held constant at 8.7 percent, the interest rate elasticity is estimated to be $-.30[=(.020-.055) \times 8.7]$. This represents a decline of about 40 percent in the interest rate sensitivity of the dependent variable. It is important to recognize that this sensitivity is reduced not only because the sensitivity of member bank share prices to interest rate changes declines but also because the legislation, by imposing uniform reserve requirements on all banks, increases the interest rate sensitivity of nonmember bank share prices.

The average level of interest rates rose to about 13 percent subsequent to the Monetary Control Act. Had the act not been in place, the share prices of member relative to nonmember banks would have declined by about 24 percent $[=100 \times-.48(13.0-8.7) / 8.7]$. The legislation, however, tempered this to a decline of only 15 percent $[=100 \times-.30(13.0-8.7) / 8.7]$.

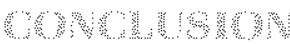

The reserve requirements imposed on the deposit liabilities of financial institutions have the properties of a tax. This tax varies with the interest rate and has differential effects across banks depending on their reserve requirements. An important change in this tax 
was made in the Monetary Control Act of 1980 . The act imposed uniform reserve requirements across all financial firms by raising reserve requirements for firms that were not members of the Federal Reserve System, while lowering them for member banks. This paper analyzes the legislation's effect on the relationship between the interest rate and the stock prices of member and nonmember commercial banks. As expected, the legislation has significantly reduced the differential effect of interest rate changes on the rela tive stock price of these banks. In the process, it has raised the after-tax earnings streams and stock prices of member banks, other things the same, while lowering both for nonmember banks.

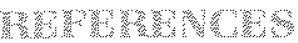

Board of Governors of the Federal Reserve System. Annual Statistical Digest, 1941-70 and 1970-79.

Brewer, Eljiah, et. al. "The Depository Institutions Deregulation and Monetary Control Act of 1980," Federal Reserve Bank of Chicago Economic Perspectives (September/October 1980), pp. 2-23.

Cargill, Thomas F., and Gillian G. Garcia. Financial Dereguiation and Monetary Control (Hoover Institution, 1982).

Fama, Eugene F. "What's Different About Banks?," Joumal of Monetary Economics (Jantuary 1985), pp. 29-39.

Gilbert, R. Alton. "Effectiveness of State Reserve Requirements," this Review (September 1978), pp. 16-28.

Gibert, R. Alton, and Jean M. Lovati. "Bank Reserve Requirements and Their Entorcement: A Comparison Across States," this Review (March 1978), pp. 22-32.

Goldberg, Lawrence G., and John T. Rose. "The Effect on Nonmember Banks of the Imposition of Member Bank Reserve Requirements - With and Without Federal Reserve Services," Journal of Finance (December 1976), pp. 1457-69.

James, Christopher. "An Analysis of Intra-Industry Differences in the Effect of Regulation: The Case of Deposit Rate Ceilings," Journal of Monetary Economics (September 1983), pp. 417-32.

Knight, Robert E. "Reserve Requirements: Part 1: Comparative Reserve Requirements at Member and Nonmember Banks," Federal Reserve Bank of Kansas City Monthly Review (April 1974), pp. $3-20$.

1980 Financial Institutions Deregulation and Monetary Control (Commerce Clearing House, Inc., 1980)

Pearce, Douglas K., and V. Vance Roley. "The Reaction of Stock Prices to Unanticipated Changes in Money: A Note," Journal of Finance (September 1983), pp. 1323-33.

"Stock Prices and Economic News," Journal of Business (January 1985), pp. 49-67.
Prestopino, Chris J. "Do Higher Reserve Requirements Discourage Federal Reserve Membership?" Journal of Finance (December 1976), pp. 1471-80.

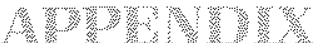

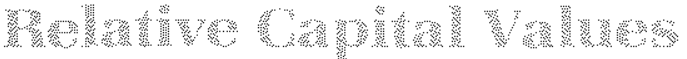

Let $P, D$ and $r$ represent capital values, deposits and the required reserve ratio as a function of deposits, respectively, while $i_{L}$ and $i_{B}$ are the lending rate and borrowing rate that are common to all banks. If the subscripts $\mathrm{M}$ and $\mathrm{N}$ indicate values for member or nonmember banks of the terms in the subscript, then:

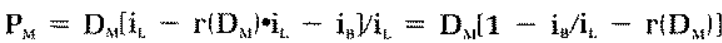

$P_{s}=D_{s}\left(i_{k}-i_{B}\right) / i_{L}=D_{N}\left(1-i_{\mathbf{R}} / i_{L}\right)$.

$P_{M} / P_{N}=\frac{D_{M}}{D_{*}}\left[1-\frac{r\left(D_{M}\right)}{1-i_{B} / i_{L}}\right]$

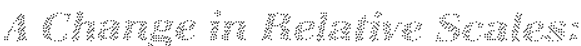

$\frac{\partial\left(\mathbf{P}_{\mathrm{N}} / \mathbf{P}_{N}\right)}{\partial\left(\mathbf{D}_{\mathrm{M}} / \mathbf{D}_{\mathrm{N}}\right)}=\left[\mathbf{1}-\frac{\mathbf{r}\left(\mathbf{D}_{\mathrm{M}}\right)}{1-\mathrm{i}_{\mathrm{B}} / \mathbf{i}_{\mathrm{L}}}\right]$

$-\left[r^{\prime}\left(D_{M}\right) \frac{\mathrm{dD}_{M}}{d\left(D_{M} / D_{N}\right)} \times \frac{1}{1-i_{\mathbb{F}} / i_{\xi_{k}}}\right] \frac{D_{M}}{D_{N}} \frac{\geq}{<} 0$

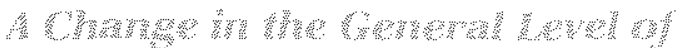

R r r

$\frac{\partial\left(\mathbf{P}_{\mathrm{N}} / \mathbf{P}_{\mathrm{N}}\right)}{\partial \mathrm{i}}=-\frac{\mathrm{D}_{\mathrm{s}}}{\mathrm{D}_{\mathrm{N}}}\left[\frac{\mathrm{i}_{\mathrm{E}}-\mathrm{i}_{\mathrm{k}}}{\mathbf{i}_{\mathrm{L}}{ }^{2}} \mathrm{~T}\left(\mathrm{D}_{\mathrm{As}}\right)\right]<0$

$\mathrm{di}_{\mathrm{b}}=\mathrm{di}_{\mathrm{s}}=\mathrm{di}$

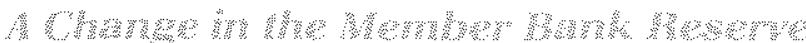

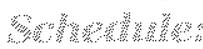

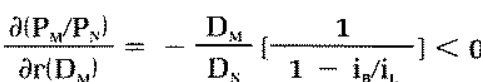

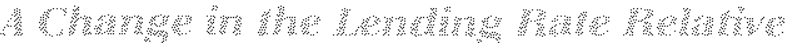

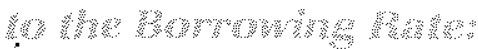

$\frac{\partial\left(\mathbf{P}_{\mathrm{u}} / \mathrm{P}_{\mathrm{X}}\right)}{\partial\left(\mathbf{i}_{\mathrm{Y}} / \mathbf{i}_{\mathrm{L}}\right)}=-\frac{\mathrm{D}_{\mathrm{s}}}{\mathrm{D}_{\mathrm{x}}}\left[\frac{\mathrm{r}\left(\mathrm{D}_{\mathrm{u}}\right)}{\left(1-\mathbf{i}_{\mathrm{R}} / \mathbf{i}_{\mathrm{L}}\right)^{3}}\right]<0$

Note that $i_{g} / i_{1}$ must be less than one. An increase in this ratio is consistent with a decline in the spread between lending and borrowing rates. 